\title{
Beyond Striga Management: Learning Videos Enhanced Farmers' Knowledge on Climate-Smart Agriculture in Mali
}

\author{
Gérard C. Zoundji ${ }^{1}$, Simplice D. Vodouhê ${ }^{1}$, Florent Okry ${ }^{2,3}$, Jeffery W. Bentley ${ }^{4}$ \& Rigobert C. Tossou ${ }^{1}$ \\ ${ }^{1}$ Department of Economics, Socio-Anthropology and Communication for Rural Development, Faculty of \\ Agricultural Sciences, University of Abomey-Calavi, 01 B.P. 526 , Cotonou, Republic of Benin \\ ${ }^{2}$ Access Agriculture, 04BP282 Cotonou, Benin Republic \\ ${ }^{3}$ National University of Agriculture of Benin, 041BP 13 Cotonou, Republic of Benin \\ ${ }^{4}$ Agro-Insight, Casilla 2695, Cochabamba, Bolivia \\ Correspondence: Gérard C. Zoundji, Department of Economics, Socio-Anthropology and Communication for \\ Rural Development, Faculty of Agricultural Sciences, University of Abomey-Calavi, 01 B.P. 526, Cotonou, \\ Benin, Tel: 229-97727273. E-mail: gezoundji@yahoo.fr, zoundjig@postgrad.unu.edu
}

Received: September 28, 2017 Accepted: October 19, $2017 \quad$ Online Published: November 7, 2017

doi:10.5539/sar.v7n1p80

URL: https://doi.org/10.5539/sar.v7n1p80

\begin{abstract}
This paper assesses the climate smart agricultural practices triggered by learning videos on integrated striga management, soil fertility and cost-benefit evaluation practices. Using household head interviews and focus group discussions, this study revealed that farmers have similar perceptions of climate change and related impacts in video-villages and in non-video-villages. However, farmers' observation of climate change and related impacts are influenced by gender; men perceived more climate change and related impacts than women. In non-video villages, few respondents adopted crop rotation, intercropping, crop diversification, improved short-cycle seed varieties and zaï techniques as climate change adaptation strategies. Videos contribute more to the adoption of crop rotation, intercropping and fertiliser application for men than for women. Videos on accounting (managing money) enable more women than men to enhance their cost-benefit evaluation practices for income improvement. During the interviews, women farmers in video-villages were eager to demonstrate their knowledge about cost-benefit evaluation. We also found that the yield of sorghum, millet and maize is higher in video-villages than in non-video-villages. Thus, using videos as an extension tool is suitable for knowledge development and leads to the high adoption of climate-smart agricultural practices for food security.
\end{abstract}

Keywords: climate change, climate-smart agriculture, learning video, agricultural innovation, striga and soil fertility management, food security, Mali

\section{Introduction}

Agriculture contributes on average 34\% to the GDP of Sub-Saharan African (SSA) countries and employs 64\% of the labour force (World Bank, 2007). It accounts for about $40 \%$ of exports and provides various ecosystem services. Agriculture and rural development are thus key pillars of the SSA economy. With subsistence agriculture practiced by most smallholder farmers, yield gaps are high and poor soils, among other constraints, add to the difficulties for sustainable agriculture and incomes. Cereals such as maize, sorghum, millets and rice remain the most consumed staple foods of most African countries (Adebayo \& Ibraheem, 2015; Macauley \& Ramadjita, 2015).

In Mali, cereals such as sorghum, millet and maize are produced for subsistence by $90 \%$ of farmers (UNDP, 2012). Sorghum and millet have considerable further potential to make food and beverages in Mali. Despite the high importance of cereals to the livelihood of people in Mali, their production has been limited by various constraints of which Striga is ranked first. Striga is a parasitic weed that infests cereals and is responsible for crop losses estimated at about 11 million tons of cereals in West Africa (Gressel et al., 2004). In addition, farmers in Mali face the problems of declining soil fertility which is a serious threat to sustainable agricultural land use (Kidron, Karnieli, \& Benenson, 2010). It is widely admitted that degraded land, depleted soil fertility and water stress contribute to low crop productivity and affect food security (Natcher et al., 2016). Striga is also a more severe problem in poor soils, one reason why Striga and soil fertility are best managed together. 
In order to manage Striga and improve soil fertility for ensuring food security, a comprehensive series of ten learning videos (Table 1) related to practical and profitable integrated striga and soil fertility management (ISSFM) were developed by Agro-Insight (an agricultural communication enterprise) for ICRISAT (International Crops Research Institute for the Semi-Arid Tropics). These videos were produced according to the zooming-in, zooming out method (Van Mele, 2006) whereby underlying scientific principles of technologies and local innovations are explained by a narrator in easy-to-understand language, interspersed with farmer interviews. In each video at least 4 experienced men and women farmers show and explain various aspects of the techniques. ICRISAT supported the distribution and use of some 10,000 copies of the "Fighting Striga" videos in Mali through many local NGOs, farmer groups, cooperatives, and extension workers. Almost all of these groups watched the videos, which had 8 language soundtracks, so everyone in Mali could understand them (Bentley et al., 2017; Van Mele, Bentley, Harun-ar-Rashid, Okry, \& van Mourik, 2016). The aim of the videos was to strengthen farmers' capacity to manage Striga and to enable them to benefit from integrated soil fertility management. Farmers were not aware of the danger of Striga seeds before watching the videos and they unconsciously let the Striga plants flower, and disperse their seeds. But after watching the videos, farmers realised that they needed to pull up the striga plants before they set seed. Many farmers have changed their farming practices to manage Striga after watching videos (Bentley et al., 2017; Van Mele et al., 2016). However, Africa faces many challenges in agricultural production. One of the key is the impact of climate change.

Indeed, climate change in many parts of the world has led to changes in temperature and rainfall patterns, depleted soils, change in wind direction and increased intensity and frequency of extreme events like droughts, floods and cyclones (Trenberth, 2007). The impacts of climate change on agriculture and food security are mainly felt through changes in crop yields, water availability, pests and diseases, and animal health (Pedercini Kanamaru, \& Derwisch, 2012). Adaptation to climate change is therefore imperative (IPCC, 2007). Changes in climate affect food and livelihood security and reverse development achievements, for example, crop failure due to frequent droughts increases poverty (Speranza, 2010).The reality of climate change demands action not just to try to slow down the process, but also to help those affected to cope with the changes taking place. The 4th assessment report of the IPCC (2007) identifies sub-Saharan Africa as extremely vulnerable because these economies are highly dependent on natural resources and rain-fed agriculture.

Mali, where the use of videos in the agricultural extension system helped farmers to control Striga and improve their cereal yields (Van Mele et al., 2016) is subject to climate issues like other African countries. Therefore, beyond Striga and soil fertility management, this study aims to assess innovation towards the climate smart agriculture practices triggered by learning videos since the videos' content focused on integrated weed management, soil fertility and conservation agriculture which constitute the key elements of mitigating climate change (Dinesh, 2016).

\section{Conceptual Framework}

Climate smart agriculture (CSA) is a concept developed by the Food and Agricultural Organisation of the United Nations (FAO) in 2010; it is aimed at adapting agriculture to climate change and to mitigating the causes of climate change (FAO, 2010). CSA practices address climate change challenges, while supporting economic growth and development of the agriculture sector. This integrative approach combines adaptation and mitigation of climate change, through "triple win" practices contributing to (i) reducing farmers' vulnerability to climatic risks (ii) reducing agricultural greenhouse gas (GHG) emissions from land use changes, deforestation, etc. (iii) and increasing farmers' incomes (World Bank \& CIAT, 2015; FAO, 2013). However, CSA has been criticised, mainly by farmer associations and civil society for focusing more on mitigation than on adaptation and for lacking specific indicators (Stabinsky, 2014). The scope of the concept has been broadening in response to this criticism and now links environmental, social and economic pillars of sustainability, and covers farm level practices, landscape level approaches, and institutional/policy level frameworks (Lipper et al., 2014). To achieve CSA there is a need to ensure proper management of resources such as soils, water, genetic resources, pest and disease control that will increase productivity, protect the environment, adapt and mitigate climate change (FAO \& World Bank, 2011). The theoretical framework of this study is based on adaptation, productivity and mitigation (APM), three interlinked pillars which are necessary for achieving CSA (Lipper et al., 2014). We build here on the APM framework (World Bank \& CIAT, 2015; FAO, 2013; Knaepen, Torres, \& Rampa, 2015) which focuses on farmers' practices or innovations to:

(i) Adapt and build resilience to climate change (Adaptation): improve soil fertility and efficiency of water use, adjust crop calendars, use different crop varieties and animal species, integrated pest, disease and weed management, empower women and the poor etc.; 
(ii) Increase agricultural productivity and food security (Productivity): a combination of adapted practices leading to better yields and stability of production and enhancing farmer's income.

(iii) Reduce or remove greenhouse gases emissions (Mitigation): land use changes and tree planting, cover cropping, crop rotation, conservation tillage, less use of agrochemicals etc., leading to reduced greenhouse gas emissions.

According to the FAO (2013), farmers' practices are considered CSA if they maintain or achieve increases in productivity as well as at least one of the other objectives of CSA (adaptation and mitigation). Drawing on the above, this study focuses on CSA by considering farmers' practices or innovations related to adaptation to climate change and agricultural productivity (food security). An innovation is the application of knowledge to achieve desired social and economic ends (Hall et al., 2001). Looking at CSA practices in the perspective of innovation systems which are made up of a range of actors involved in generating and using new knowledge, technologies, management practices and institutional relationships (Matsaert, Ahmed, Islam, \& Hussain, 2005) is important to understand the role played by interconnected actors in the adoption of CSA practices. In this perspective, the actors/institutions such as ICRISAT, video dissemination organisations, and farmers are seen to play an important role in the adoption of CSA practices, since innovations do not emerge by themselves but may be triggered by a technical novelty, policy initiative or a new social arrangement (Leeuwis, 2004).

\section{Method}

\subsection{Research Area}

The present study was carried out in Republic of Mali (Figure 1) which is a landlocked country in West Africa. It is a large, flat and arid nation with about $1,240,000$ sq. $\mathrm{km}$. The weather is dry and hot from February to June, wet and relatively mild from June to November, and dry and cooler from November to February. Mali has three climate zones. The northernmost Saharan zone has almost no rainfall with mean daily temperature highs of $48^{\circ} \mathrm{C}$ and lows of $5^{\circ} \mathrm{C}$. In the Sahel, the continent-spanning transitional region between the Sahara and equatorial Africa, annual rainfall averages $100-200 \mathrm{~mm}$ with a mean daily temperature of $29^{\circ} \mathrm{C}$. The third, Sudanic or Sudanian climate zone averages $700-1,300 \mathrm{~mm}$ of annual rainfall with a mean daily temperature of $27^{\circ} \mathrm{C}$. Climate change is already a significant threat to the country's development, due in part to erratic rainfall, increased crop pests, rainfall shortages, and breaks during critical growing periods, as well as desertification over the last 50 years (FAO, 2008). The most highly stressed regions of the country are in the south where agriculture is concentrated, including Sikasso and Segou which are included in this study. Agriculture in Sikasso is cotton-based, with maize, sorghum and millet as major traditional staple cereal crops. The Sikasso Region is in transition from a largely low input, subsistence agriculture to an increasingly intensified commercial farming system. The Ségou Region is crossed by two important waterways: the Niger and the Bani Rivers, allowing irrigation. The main rain-fed crop is millet, with cowpea as an important secondary crop, and sorghum cultivated in lower, wet and heavier soils. The Sikasso and Ségou regions were chosen for the study because of their similar societal features as well as comparable climate and seasonal variability patterns (Kergna \& Dembele, 2016).

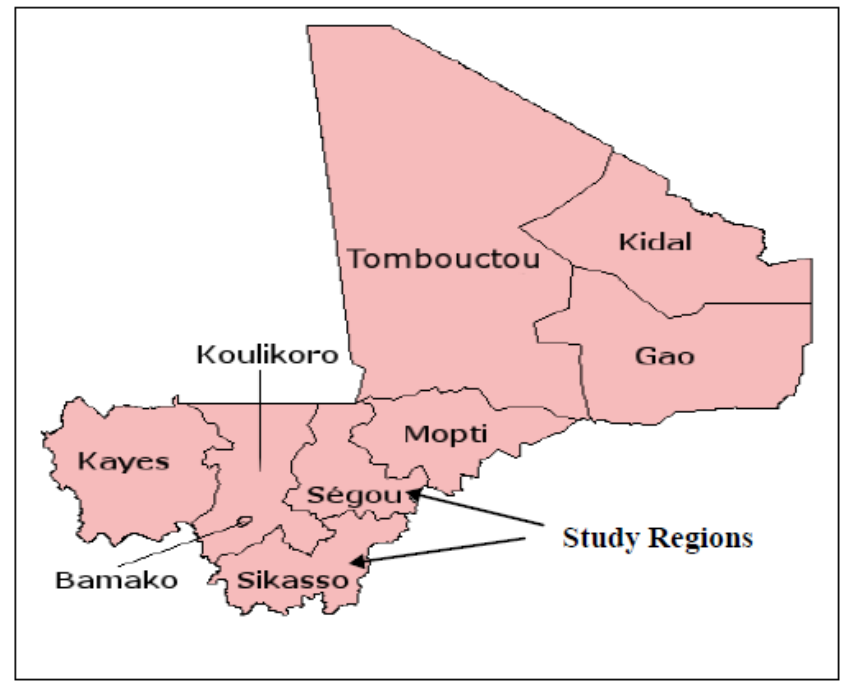

Figure 1. Map of Mali with different regions 


\subsection{Research Methods}

The study was conducted from September 2016 to October 2016 in the regions of Segou and Sikasso of Mali, where ICRISAT in partnership with the farmers' organization Union des Agriculteurs du Cercle de Tominian (UACT) and NGO Association Malienne d'Eveil au Développement Durable (AMEDD) operate to improve the livelihood of farm families. UACT and AMEDD both disseminated new technologies through the "Fighting Striga" videos. UACT showed the videos by identifying a farmer in each village who owned video viewing equipment and organising a public screening, while AMEDD set appointments with the villages and took enough equipment to screen the video. Both organisations left copies of DVDs with the "Fighting Striga" videos for community members to watch on their own. A short description of the "Fighting Striga" videos is presented in Table 1.

Table 1. Short description of Fighting Striga videos

\begin{tabular}{|c|c|}
\hline Video title & Short description \\
\hline 1- Striga Biology & $\begin{array}{l}\text { Striga is a parasite weed of cereal crops. The weed develops from tiny seeds, and not (as many farmers } \\
\text { believe) from the roots of the cereal crops. Rather than merely competing for space and nutrients like other } \\
\text { weeds, Striga attaches itself to the host's root, and remains underground and unseen for weeks. Knowing its } \\
\text { life cycle is the start of proper control }\end{array}$ \\
\hline $\begin{array}{l}\text { 2- Integrated approach } \\
\text { against striga }\end{array}$ & $\begin{array}{l}\text { Striga causes more damage to cereal crops in poor soil, so both problems have to be tackled together. Organic } \\
\text { and chemical fertiliser can help to manage striga. A legume intercrop can kill Striga. Remaining Striga plants } \\
\text { can be hand pulled before they flower. }\end{array}$ \\
\hline 3- Succeed with seeds & $\begin{array}{l}\text { Farmers can test crop varieties to identify Striga-resistant ones that perform well under local conditions. } \\
\text { Growing resistant varieties is one of the strategies of integrated Striga and soil fertility management }\end{array}$ \\
\hline $\begin{array}{l}4 \text { Composting to beat } \\
\text { striga }\end{array}$ & $\begin{array}{l}\text { Compost helps to fight Striga. Farmers can make compost from manure and crop residues, even in arid } \\
\text { places. }\end{array}$ \\
\hline 5- Micro-dosing & Application of small amounts of fertiliser to the base of the plant can save fertiliser while improving yields. \\
\hline $\begin{array}{l}\text { 6- Animals and trees for a } \\
\text { better crop }\end{array}$ & $\begin{array}{l}\text { Cattle that browse on leaves and seed pods of trees can fertilise the crops with their manure. Trees and } \\
\text { livestock play a crucial role in obtaining a productive soil and crop. }\end{array}$ \\
\hline 7- Storing cowpea seed & $\begin{array}{l}\text { Techniques to prevent damage by insect pests in cowpea seed, so cereals can be intercropped with this useful } \\
\text { legume. Intercropping a cereal crop with legumes is part of integrated Striga and soil fertility management. }\end{array}$ \\
\hline 8- Grow row by row & $\begin{array}{l}\text { Legumes like cowpeas are trap crops. Striga germinates near legumes, but cannot attach to their roots. A } \\
\text { legume crop helps to manage striga. }\end{array}$ \\
\hline $\begin{array}{l}\text { 9- Joining hands against } \\
\text { striga }\end{array}$ & Farmers can avoid the drudgery of weeding by working together. \\
\hline 10- Let's talk money & $\begin{array}{l}\text { A participatory tool to measure the cost-benefit of new technologies, like Striga management, with farm } \\
\text { communities. This tool helps farmers to make decisions }\end{array}$ \\
\hline
\end{tabular}

Source: Access Agriculture (www.accessagriculture.org)

The field work covered four villages (Daga and Hasso in Segou, Sirakelé and N'Tonasso in Sikasso) where the videos had been intensively shown (video-villages) in late 2012 and two control villages (Bolimasso in Segou and N'Togonasso in Sikasso) where no videos were screened (non-video-villages). Villages were selected based on the importance of cereal crop growing and the accessibility of the village.

This study included semi-structured interviews with 122 farmer household heads who participated on a voluntary basis. The sampled households comprise farmers who had lived all or most of their life in the selected villages, and were able to assess changes in climate. Household head interviews were combined with focus group discussions (FGD) (Kitzinger, 1994), organised in each selected village to crosscheck information. The FDG group consisted of village leaders, women's representatives, village counsellors, youth representatives and other persons involved in agricultural decision-making at the local level. Three FGD were organised with about eight farmers in each village, per Greenbaum (2000) who suggested that a focus group should be with seven to ten people. We conducted 18 FGD with 151 participants (Table 2). The focus group discussions were recorded, translated (from Bambara to French) and transcribed as literally as possible. All respondents were of age 40 or above and their main economic activity was subsistence agriculture. Key informant interviews were conducted with 21 extension workers, representatives of institutions and non-government organisations working with farmers in the selected villages. Interviews with extension workers were used to triangulate the information from household interviews and focus group discussions. The data collection methods are summarised in Table 2. 
Table 2. Overview of data collection methods

\begin{tabular}{llccc}
\hline \multicolumn{2}{c}{ Study Area } & \multicolumn{3}{c}{ Data collection methods } \\
\cline { 3 - 5 } & & $\begin{array}{l}\text { Household head } \\
\text { interviews }(\mathrm{n}=122)\end{array}$ & $\begin{array}{c}\text { FGD participant } \\
(\mathrm{n}=151)\end{array}$ & $\begin{array}{c}\text { Extension workers } \\
\text { interviews (n=21) }\end{array}$ \\
\hline Video-villages & Daga & 21 & 27 & 21 \\
& Hasso & 20 & 24 & \\
& Sirakelé & 20 & 26 & \\
& N'Tonasso & 19 & 23 & \\
\hline \multirow{2}{*}{ Non-video- villages } & Bolimasso & 22 & 25 & $\mathbf{2 1}$ \\
& N'Togonasso & 20 & 26 & \\
\hline Total & - & $\mathbf{1 2 2}$ & $\mathbf{1 5 1}$ & \\
\hline
\end{tabular}

Source: Field data, 2016

Qualitative data were analysed by using the climate-smart agriculture framework (APM) presented above. For quantitative data, pairwise comparison was used to evaluate the difference between the proportion of household heads who used the videos to learn and those who did not use the videos. The correlation between video watching and adoption of climate-smart agricultural practices was evaluated with Chi-square tests. This was also performed on a contingency table of gender and climate-smart agricultural practices to evaluate the dependence between these variables. For cereal yields, ANOVA (General Linear Model) was performed to assess the difference between the household types and gender. When significant difference between types of household was found, a Student-Newman and Keuls test (SNK-test) was applied in the R package agricolae. All the statistical analyses were performed using R 3.4 (R Core Team, 2017).

\section{Results and Discussion}

\subsection{Respondents' Socio-demographic Characteristics}

Most of the household heads interviewed were men (75\%). In most West African cultures, males are considered to be the heads of households (see, for example Amaza et al., 2008). Most of the household heads (73\%) were between 40 and 50 years old. Few of the household heads (15\%) received basic education (primary school) and $85 \%$ had no formal education. This shows the importance of making farmers' training materials in their own language, using the spoken rather than the written word (Mundy \& Sultan, 2001). The socio-demographic characteristics of household heads are summarised in Table 3.

Table 3. Household head' socio-demographic characteristics $(\mathrm{n}=122)$

\begin{tabular}{llcc}
\hline & Characteristics & $\mathbf{n = 1 2 2}$ & $\mathbf{\%}$ \\
\hline \multirow{4}{*}{ Age } & $40-50$ & 89 & 72.95 \\
& $51-60$ & 22 & 18.03 \\
& $>61$ & 11 & 9.01 \\
\hline \multirow{2}{*}{ Gender } & Male & 91 & 74.59 \\
& Female & 31 & 25.49 \\
\hline \multirow{2}{*}{ Education } & No formal education & 104 & 85.24 \\
& Finished primary school & 18 & 14.75 \\
\hline
\end{tabular}

Source: Field data, 2016

\subsection{Farmers' Observation of Climate Change and Related Impacts}

Before we carried out this study, $87 \%$ of male-headed households and $19 \%$ female-headed household had heard of climate change. The women said that they were unaware of climate change because the agricultural extension services do not always consider them to be farmers and women are left out of the community discussions or meetings organised by the extension workers. In a similar vein, Katungi, Edmeades and Smale (2008) reported that women do not benefit from extension programs for farmers in Uganda. Furthermore, social norms in most West African constrain many women from communicating freely with men who are not from their families. In order to overcome this gender gap in accessing extension services, policy makers must promote the use of videos which facilitate information access to all rural people (Zoundji et al., 2016).

During the interview, all respondents expressed interested in discussing climate variability and wanted to know what strategies they could adopt to increase their ability to cope with the change. However, the following 
changes in seasons and climate were observed over the past 10-20 years by respondents. The rainy seasons are becoming shorter and the rains start later or end earlier, as reported by most households (80\%), followed by increasingly strong winds and higher temperatures, mentioned by $78 \%$ of households. Severe droughts are becoming more frequent, as reported by $69 \%$ of respondents. Farmers have observed negative impacts of climate, as disaggregated by gender in Figure 2 .

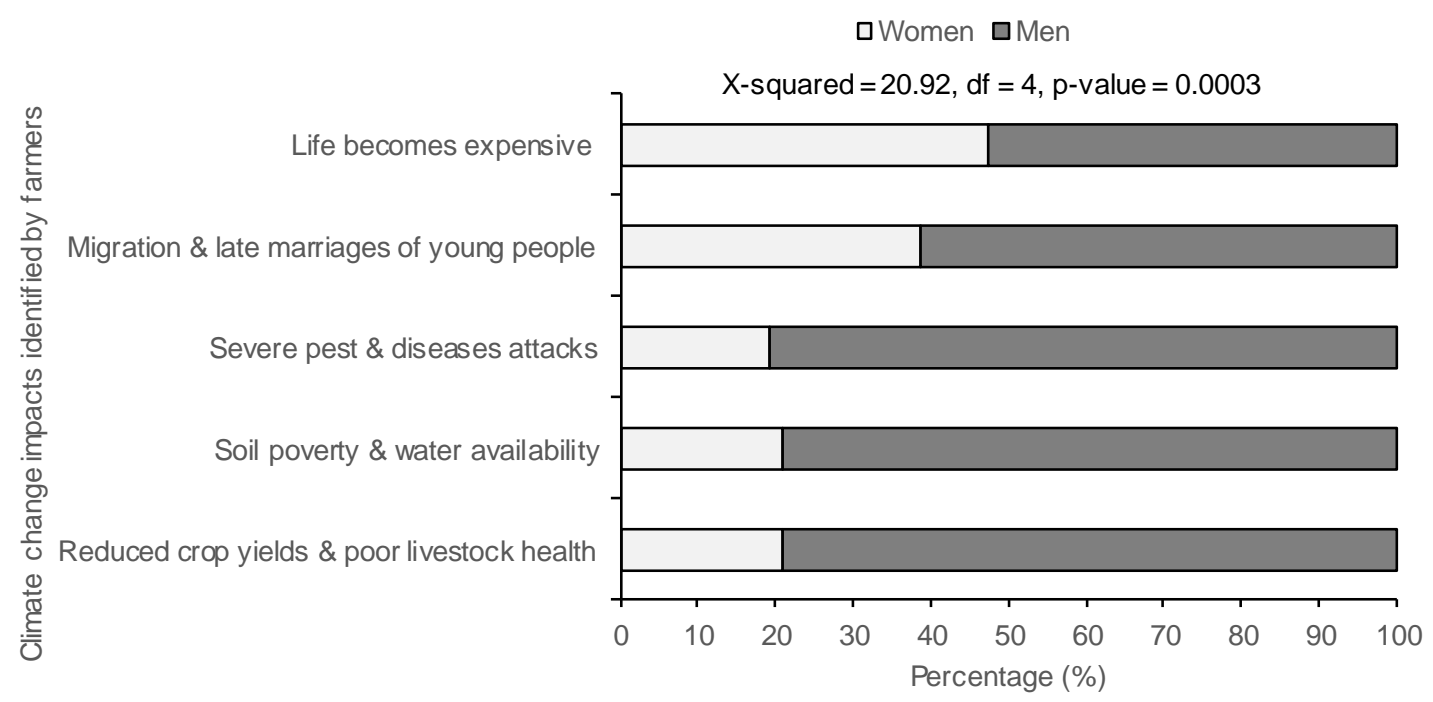

Figure 2. Impacts of climate change identified by farmers

Source: Field data, 2016

Men noticed reduced crop yields and poor livestock health, soil poverty, less water availability, and more pest and disease problems (as the impacts of climate change), while households headed by women noted that cost of living increases, more migration and delayed marriages. Men pay attention to climate change's impacts on agriculture, while women are more likely to notice social change. There are gendered patterns of impacts of climate change. This may be because in West Africa, many women do not control revenue from agriculture, but they are active in small trade (Diiro et al., 2016; Fafchamps, Gabre-Madhin, \& Minten, 2005). Farmers in the focus group discussions (FGD) identified pest and disease problems (54\%), followed by reduced crop yields, poor livestock health $(52 \%)$ impoverished soil and difficulties of water management $(42 \%)$. Interviews with extension workers confirmed the men's observations and described declining crop yields, scarcity of water, increased pest and disease problems, deteriorating animal health and others as mainly impacts of climate change on rural development (see Zoundji et al., 2017 for similar observations). Other studies of farmers' observations confirmed the above as the main climate change impacts in Mali (Ebi et al., 2011; Diiro et al., 2016).

Farmers in video-villages and in non-video-villages made similar observations of climate change and its impacts, probably because all the villages are receiving about the same quality and quantity of climate information. Conflict between farmers and pastoralists was only mentioned by some farmers in N'Togonasso, the non-video-village of Sikasso. This is probably because Sikasso is most suitable for arable farming and has become a region for livestock rearing and transhumance in Mali. The clashing interests of pastoralists and farmers often lead to conflicts, which are quite common in Mali, especially when livestock damage crops.

Household heads' observations of climate change corroborated focus group responses and confirmed what was described as climate change impacts in other areas in Mali and other rural Sahel (Pedercini et al., 2012). Farmers' must observe climate change before they can sustainably adapt to it (Koch, Vogel, \& Patel, 2006).

\subsection{Farmers'Adaptation and Resilience Building to Climate Change}

Farmers use various techniques to adapt to climate change, with differences between video-villages and non-video-villages (Table 4). Theses coping strategies build on farmers' adaptation and resilience to climate change. In the video-villages, our informants said the most common agricultural adaptation strategies include crop rotation, intercropping, fertiliser application, crop diversification, use of improved short-cycle seed varieties, tree planting and use of zaï pits (shallow planting pits to capture water).

Fertiliser application in zaï pits were not mentioned during individual and group discussions in non-video 
villages. Farmers had no information on this practice, but were willing to learn more about it. Very few respondents had adopted crop rotation, intercropping, crop diversification, improved short-cycle seed varieties and zaï pits as climate change adaptation strategies in non-video villages, which received little or no information about these innovations.

Farmers in video-villages were more likely to report easy contact with extension workers who visit the village and more community meetings. Video-villages were more likely to mention other adaptation methods such as income generating activities, including savings-and-loan activities, cost-benefit analysis before selling products and hand-pulling of Striga as a paid service (i.e. charging farmers to uproot the weeds in their fields). Making money through hand-pulling of Striga was not mentioned in non-video villages. The difference observed in video-villages and non-video-villages was explained by Madam Nakisso, of Hasso village, who said "learning videos help us to see a visual, convincing demonstration and practical explanation from other farmers in our own language of the entire process of technology and facilitated it adoption". Farmers' adaptation to climate change involves an array of technical and institutional responses, which can be stimulated by local or outside knowledge (FAO, 2010). The "Fighting Striga" videos disseminated by local NGOs inspired farmers to engage in alternative ways of crop and soil fertility management, off-farm activities etc. As results of these practices, farmers improved their resilience, increased yields and can sequester more carbon. The farming practices which preserve and improve soil (crop rotation, use of compost or residue management etc.) contribute to carbon sequestering (Govaerts et al., 2009). So, these agriculture practices are adaptive responses to climate change. However, these practices demand labour. For example, composting with organic matter requires work, especially to build and maintain a compost pit. Nevertheless, the use of manure has proven highly effective as a low-cost CSA technique (Nkwake, Magistro, \& Horjus, 2014).

During the interview, women farmers in particular were eager to demonstrate their experiences with the analysis of cost-benefit evaluation. Some women's groups in the villages of Daga and Sirakélé have started selling improved cereal seed since farmers' demands of it were increased after watching videos. Farmers usually spent 2-3 USD to travel to a town where they could buy improved seed. So, the knowledge acquired from the videos 'Let's talk money' inspired two women's group to become seed dealers in the village. This initiative started in 2014 in Daga village with a woman leader, Madam Dembelé. In 2015, women in Sirakélé village also started to sell improved seed because of Madam Dembelé. She is from Sirakélé village and married into Daga village. Madam Dembelé is a key element for the social network which triggers innovation in two villages. The development of improved seed trading at the village level reinforces farmers' access to improved technology and can be a strong driver in facilitating the widespread diffusion of new technologies or information for sustainable livelihoods (see Van Mele et al. 2011). This is in line with findings of Leeuwis and Hall (2013) who report that agricultural extension should not only focus on sharing information, but should also engage in development tasks such as facilitating farmers' access to inputs.

Farmer knowledge development of CSA practices is strongly connected to an agricultural extension approach. However, many farmers do not acknowledge the results of frequent visits from extension agents in their villages; while in the field, we met several development partners such as World Neighbours, World Vision, and the NGO IRD, which were working intensively with farmer leaders. As explained by Madam Bohan in Daga village, "Toubab (white people) used to come to this village and discussed or worked with our farmer leaders and their relatives. We heard that those external people were implementing agricultural projects with farmer leaders". So, most of information or agricultural practices promoted by development partners were not always shared with other farmers. Farmers' access to relevant CSA practices or improved agricultural technology is limited by institutions which exclude many farmers who need agricultural information. In order to overcome this constraint, learning video as an agricultural extension tool may be the best and most cost effective method to reach more farmers and to give a fair chance to anyone who is interested in agriculture (Zoundji et al., 2016).

Table 4 shows that the households who viewed the videos were more likely to adopt climate-smart agricultural practices. In the video-villages, farmers are more likely to crop adopt rotation, intercropping and fertiliser application, and men are more likely to adopt than women. For accounting (cost-benefit evaluation practices), videos enable more women than men to enhance their accounting practices for income improvement. 
Table 4. Farmers' practices towards sustainable agricultural productivity and incomes

\begin{tabular}{|c|c|c|c|c|c|c|c|}
\hline \multirow[t]{2}{*}{ Categorization } & \multirow[t]{2}{*}{$\begin{array}{l}\text { Climate-smart } \\
\text { practices }\end{array}$} & \multicolumn{2}{|c|}{$\begin{array}{l}\text { Video villages } \\
\qquad(\mathrm{n}=80)\end{array}$} & \multicolumn{2}{|c|}{$\begin{array}{c}\text { Non-video } \\
\text { villages } \\
(\mathrm{n}=42)\end{array}$} & \multirow{2}{*}{$\begin{array}{c}\begin{array}{c}\text { Video } \\
\text { villages } \\
(\mathrm{n}=80)\end{array} \\
(\%)\end{array}$} & \multirow{2}{*}{$\begin{array}{c}\begin{array}{c}\text { Non-video } \\
\text { villages } \\
(\mathrm{n}=42)\end{array} \\
(\%)\end{array}$} \\
\hline & & $\begin{array}{c}\text { Women } \\
(\%)\end{array}$ & $\begin{array}{c}\text { Men } \\
(\%)\end{array}$ & $\begin{array}{c}\text { Women } \\
(\%)\end{array}$ & $\begin{array}{c}\text { Men } \\
(\%) \\
\end{array}$ & & \\
\hline \multirow{6}{*}{$\begin{array}{l}\text { Crop and soil Management } \\
(\mathrm{X} \text {-squared }=18.43, \mathrm{df}=5, \\
\text { p-value }=0.002)\end{array}$} & $\begin{array}{l}\text { Crop rotation combined with } \\
\text { intercropping }\end{array}$ & 26 & 77 & 17 & 40 & $99 \mathrm{a}$ & $57 \mathrm{~b}$ \\
\hline & $\begin{array}{l}\text { Fertiliser application: adding } \\
\text { compost, manure or micro-doses } \\
\text { of mineral fertiliser to the base of } \\
\text { the plants }\end{array}$ & 20 & 79 & 0 & 0 & $99 \mathrm{a}$ & $0 \mathrm{~b}$ \\
\hline & Crop diversification & 20 & 73.75 & 7.14 & 45.23 & $93.75 \mathrm{a}$ & $52.38 \mathrm{~b}$ \\
\hline & $\begin{array}{l}\text { Use of improved short-cycle seed } \\
\text { varieties }\end{array}$ & 13.75 & 63.75 & 2.38 & 14.28 & $77.5 \mathrm{a}$ & $16.66 \mathrm{~b}$ \\
\hline & Tree planting & 11.25 & 56.25 & 0 & 64.28 & $67.5 \mathrm{a}$ & $64.28 \mathrm{~b}$ \\
\hline & $\begin{array}{l}\text { Use of zaï pots for water capture } \\
\& \text { fertiliser application }\end{array}$ & 5 & 46.25 & 0 & 0 & $51.25 \mathrm{a}$ & $0 \mathrm{~b}$ \\
\hline \multirow[t]{2}{*}{$\begin{array}{l}\text { Social learning }(X \text {-squared }= \\
0.95, \mathrm{df}=1, \mathrm{p} \text {-value }=0.329)\end{array}$} & $\begin{array}{l}\text { Easy contact with extension } \\
\text { workers }\end{array}$ & 15 & 71.25 & 0 & 45.23 & $86.25 \mathrm{a}$ & $45.23 b$ \\
\hline & $\begin{array}{l}\text { More community meetings for } \\
\text { knowledge exchange and } \\
\text { decision making }\end{array}$ & 6.25 & 66.25 & 0 & 38.09 & $72.5 \mathrm{a}$ & $38.09 \mathrm{~b}$ \\
\hline \multirow{3}{*}{$\begin{array}{l}\text { Income generating activities } \\
\text { for empowerment }(\mathrm{X} \text {-squared } \\
=13.80, \mathrm{df}=2 \text {, } \mathrm{p} \text {-value }= \\
0.001)\end{array}$} & $\begin{array}{l}\text { Farmers engage in saving \& loan } \\
\text { activities }\end{array}$ & 26.25 & 2.5 & 11.9 & 0 & $28.75 \mathrm{a}$ & $11.9 \mathrm{~b}$ \\
\hline & $\begin{array}{l}\text { Use of accounting knowledge to } \\
\text { analyse cost \& benefits before } \\
\text { selling products }\end{array}$ & 25 & 33.75 & 16.66 & 14.28 & $58.75 \mathrm{a}$ & $30.95 b$ \\
\hline & $\begin{array}{l}\text { Hand-pulling of Striga as paid } \\
\text { service }\end{array}$ & 26.25 & 0 & 0 & 0 & $26.25 \mathrm{a}$ & $0 \mathrm{~b}$ \\
\hline
\end{tabular}

NB: The line with different letters means significant difference between video village and non-video village

In video villages, the adoption of income generating activities for empowerment depend on gender ( $\mathrm{P}$-value<0.001) contrary to crop and soil management $(\mathrm{P}$-value $=0.455)$ and social learning $(\mathrm{P}$-value $=0.236)$. In non-video villages, the adoption of crop and soil management practices depend on gender ( $\mathrm{P}$-value $=0.013$ ) contrary to income generating activities for empowerment ( $\mathrm{P}$-value $=0.114)$, and social learning $(\mathrm{P}$-value=1)

\subsection{Farmers' Responses to Food Security under Climate Change Condition}

Reduction of crop yields was the most important impact of climate change mentioned by farmers and extension workers (see Figure 2). Innovative practices (see Table 5) were used by farmers to increase agricultural productivity and reduce food insecurity in the face of the newly unpredictable climate. Table 4 shows the yield of sorghum, millet and maize, which are high in video-villages and low in non-video villages. Sorghum, millet and maize yields in the video-villages have increased by $14 \%, 30 \%$ and $15 \%$ respectively when compared to non-video villages. There is no influence on the increase of the yield between female and male-headed households. Only the type of household (video or non-video) significantly influences cereal yields (Table 5). Increased yields would contribute to food security and improvement of farmers' social and economic status. The yields in the video villages are higher than the national averages which were $1048 \mathrm{~kg} / \mathrm{ha}$ for sorghum, $959 \mathrm{~kg} / \mathrm{ha}$ for millet and $2538 \mathrm{~kg} / \mathrm{ha}$ for maize (Ministère de l'Agriculture [MA], 2016). Among the factors contributing to high productivity of cereal crops are the crop and soil management practices developed by farmers after watching the videos. Farmers recognised the increase of yield and link it is mainly to the adoption of crop rotation and intercropping with fertiliser application using composted manure and zaï pits. Therefore, the increases in yield might be related to the use of videos as an agricultural extension tool, which stimulates and inspires farmers to consider new ideas and apply knowledge in farming. Furthermore, in three out of four video villages, household heads explained that technologies developed in the videos are based on farmers' existing technical knowledge. This facilitates the adoption of technology (Van Mele, 2006). Taking advantage of farmers' 
existing knowledge to develop a new technology would be a key element to enhance its adoption. Bishop-Sambrook et al., (2004) found that adoption of rippers for conservation tillage to set up seedbeds was higher in villages with experience with draught animals than where farmers used only hand hoes. Using videos as extension tools, which are based on farmers' experiences and combine visual and verbal communication methods is suitable for knowledge development and lead to high adoption of CSA practices.

Table 5. Farmers' estimation of crop yield (kg/ha) for growing season 2015

\begin{tabular}{|c|c|c|c|c|c|c|c|}
\hline \multirow{2}{*}{ Crops } & \multicolumn{3}{|c|}{ Videos villages } & \multicolumn{3}{|c|}{ Non videos villages } & \multirow[t]{2}{*}{ Statistic W of Mann-Whitney Tes } \\
\hline & Mean & $\mathrm{CV}(\%)$ & Median & Mean & $\mathrm{CV}(\%)$ & Median & \\
\hline Maize & $2598.10 \pm 24.70$ & 8.49 & 2500 & $2247.60 \pm 23.50$ & 6.77 & 2250 & $267.5^{* * *}$ \\
\hline Millet & $1065.00 \pm 10.30$ & 8.69 & 1050 & $813.10 \pm 17.00$ & 13.52 & 800 & $74 * * *$ \\
\hline Sorghum & $1082.30 \pm 8.42$ & 6.96 & 1050 & $945.20 \pm 19.50$ & 13.36 & 950 & $523.5 * * *$ \\
\hline
\end{tabular}

***significant at 0.001

Source: Field data, 2016

Table 6. Analysis of variance performed on yield

\begin{tabular}{lllllll}
\hline \multirow{2}{*}{ Source of variation } & \multicolumn{2}{l}{ Sorghum } & \multicolumn{2}{l}{ Millet } & \multicolumn{2}{l}{ Maize } \\
\cline { 2 - 7 } & Df & F-value & Df & F-value & Df & F-value \\
\hline Type of household (videos or non-videos) & 1 & $55.81^{* * *}$ & 1 & $176.69 * * *$ & 1 & $83.43 * * *$ \\
Gender & 1 & $0.97 \mathrm{~ns}$ & 1 & $0.38 \mathrm{~ns}$ & 1 & $0.12 \mathrm{~ns}$ \\
Type of household x Gender & 1 & $0.05 \mathrm{~ns}$ & 1 & $0.14 \mathrm{~ns}$ & 1 & $0.17 \mathrm{~ns}$ \\
\hline
\end{tabular}

*** significant vat $0.001, \mathrm{~ns}$ non-significant

\section{Conclusion}

Both women and men are concerned about climate change and use diverse strategies to adapt to it. The most common ones include crop rotation, intercropping, crop diversification, use of improved seed varieties, use of compost, and use of zaï pits for water storage and fertiliser application. Organisations like ICRISAT, UACT and AMEDD facilitated video screening, which inspired farmers to try and adapt CSA innovations. Organisations played an important role and served as channels through which farmers accessed reliable and credible information to adopt CSA practices. For the farmers, it is not merely the information that is important, but also how they acquired it. Watching the videos played an important role in farmer innovation. After public screenings, UACT and AMEDD left copies of the DVDs with "Fighting Striga" videos which the rural people could watch when they wanted to. In the villages covered by UACT, farmers promptly continued to watch videos a day after the public screening, while it took about two months before farmers watched videos after public screening in the villages covered by AMEDD. Recall that UACT showed the videos on equipment borrowed from community members, which may have increased their confidence to screen videos for their neighbours, while AMEDD supplied the video viewing gear. Involving farmers in the process of screening videos may encourage them to show videos later, to other community members.

We observed a significant difference between video villages and others as responses to climate change. Although the "Fighting Striga" videos were not focused explicitly on CSA technologies, the sustainable practices adopted by farmers did respond to climate change and CSA objectives. By managing Striga, farmers achieve agricultural resilience to climate change which improved agricultural productivity. Farmers attribute increased crop yields to the adoption of the sustainable practices of soil and crop management, contributing to food security under a changing climate. Farmers' practices are considered CSA if they maintained or achieved increases in productivity (FAO, 2013). Agricultural extension services using videos as learning tools proved successful because the learning videos went beyond showing how to use each technology and also explained why they would work. Thus, farmers went beyond just repeating what was shown in videos, and engaged in the learning process and drew lessons from their own experiences. As climate change presents challenges to farmers that demand innovative responses, using learning videos in agricultural extension to communicate climate information will increase farmers' adaptation capacities which are crucial for climate smart agriculture development. 


\section{Acknowledgements}

Financial support for this research was provided by the Video for Farmers Project, implemented by Access Agriculture and funded by the Swiss Agency for Development and Cooperation [Project number 7F-08378.01]. This work was also supported by Ministry of High Education and Scientific Research of the Republic of Benin through the initiative "Appui aux doctorants" 2015-2016. We gratefully acknowledge the field assistance of Amadou I. Sidibé and Samuel Guindo. We are also grateful to our respondents for their availability and collaboration throughout the fieldwork period. We would like to thank the anonymous peer reviewers for their valuable comments.

\section{References}

Adebayo, O. O., \& Ibraheem, I. O. (2015). The current status of cereals (maize, rice and sorghum) crops cultivation in Africa: Need for integration of advances in transgenic for sustainable crop production. International Journal of Agricultural Policy and Research, 3(3), 233-245.

Amaza, P.S., Adejobi, A.O., and Kwaghe P.V. 2008 Poverty and its determinants among farming households in West Africa: Empirical evidence from Borno State, Nigeria. Journal of Food, Agriculture \& Environment 6 (3\&4): 406-411.

Bentley, J. W., Van Mele, P., Touré, S., van Mourik, T., Guindo, S., \& Zoundji, G. (2017). Seeds of the devil weed. Local knowledge and learning from videos in Mali. Chapter 7. In P. Sillitoe (Ed.), Indigenous Knowledge: Enhancing its contribution to Natural Resources Management. Wallingford, UK: CABI.

Bishop-Sambrook, C., Kienzle, J., Mariki, W., Owenya, M., \& Ribeiro, F. (2004). Conservation Agriculture as a Labour Saving Practice for Vulnerable Households. A Study of the Suitability of Reduced Tillage and Cover Crops for Households under Labour Stress in Babati and Karatu Districts, Northern Tanzania. IFAD, FAO, 80p.

Diiro, G., Petri, M., Zemadim B., Sinare, B., Dicko, M., Traore, D., \& Tabo, R. (2016). Gendered Analysis of Stakeholder Perceptions of Climate Change, and the Barriers to its Adaptation in Mopti Region in Mali. Research Report no. 68. Patancheru 502 324. Telangana, India: International Crops Research Institute for the Semi-Arid Tropics. 52 pp.

Dinesh, D. (Ed). (2016). Agricultural practices and technologies to enhance food security, resilience and productivity in a sustainable manner: Messages to SBSTA 44 agriculture workshops. CCAFS Working Paper no. 146. Copenhagen, Denmark: CGIAR Research Program on Climate Change, Agriculture and Food Security (CCAFS).

Ebi, K. L., Padgham, J., Doumbia, M., Kergna, A., Smith, J., Butt, T., \& McCarl., B. (2011). Smallholders' adaptation to climate change in Mali, Climatic Change. https://doi.org/10.1007/s10584-011-0160-3

Fafchamps, M., Gabre-Madhin, E., \& Minten, B. (2005). Increasing returns and market efficiency in agricultural trade. Journal of Development Economics 78:406-442. https://doi.org/10.1016/j.jdeveco.2004.10.001

FAO, \& World Bank. (2011). Identifying Opportunities for Climate-Smart Agriculture Investments in Africa, FAO \& World Bank Final report.

FAO. (2008). Climate Change Adaptation and Mitigation in the Food and Agriculture Sector. Technical Background Document from the Expert Consultation held on March 5-7, 2008. In High-level Conference on Food Security: The Challenges of Climate Change and Bioenergy, June 3-5, 2008, Rome.

FAO. (2010). Climate Smart Agriculture Policies, Practices and Financing for Food Security, Adaptation and Mitigation. FAO, Rome.

FAO. (2013). Climate-Smart Agriculture - Sourcebook on Climate-Smart Agriculture, Forestry and Fisheries. Rome: FAO.

Govaerts, B., Verhulst, N., Castellanos-Navarrete, A., Sayre, K. D., Dixon, J., \& Dendooven, L. (2009). Conservation Agriculture and Soil Carbon Sequestration: Between Myth and Farmer Reality. Critical Reviews in Plant Science, 28, 97-122, 2009. https://doi.org/10.1080/07352680902776358

Greenbaum, T. L. (2000). Moderating focus groups: A practical guide for group facilitation; Thousand Oaks, CA: Sage Publications. https://doi.org/10.4135/9781483328522

Gressel J., Hanafi A., Head, G., Marasas W., Obilana A. B., Ochanda J., Souissi T., \& Tzotzos, G. (2004). Major heretofore intractable biotic constraints to African food security that may be amenable to novel biotechnological solutions. Crop Protection, 23, 661-689. https://doi.org/10.1016/j.cropro.2003.11.014 
Hall, A.J., Sivamohan, M.V.K., Clark, N., Taylor, S., \& Bockett, G. (2001). Why Research Partnerships Really Matter: Innovation Theory, Institutional Arrangements, and Implications for Developing New Technology for the Poor. World Development, 29(5), 783-797. https://doi.org/10.1016/S0305-750X(01)00004-3

IPCC. (2007). Climate Change, Synthesis Report, an Assessment of the Intergovernmental Panel on Climate Change.

Katungi, E., Edmeades, S., \& Smale, M. (2008). Gender, social capital and information exchange in rural Uganda. Journal of International Development, 20(1), 35-52. https://doi.org/10.1002/jid.1426

Kergna, A. O., \& Dembele, D. (2016). Status of Agricultural Innovations, Innovation Platforms, and Innovations Investment. 2015 PARI project country report: Republic of Mali. Forum for Agricultural Research in Africa (FARA), Accra Ghana.

Kidron, G. J., Karnieli, A., \& Benenson, I. (2010). Degradation of soil fertility following cycles of cotton-cereal cultivation in Mali, West Africa: A first approximation to the problem. Soil \& Tillage Research, 106, 254-262. https://doi.org/10.1016/j.still.2009.11.004

Kitzinger, J. (1994). The methodology of Focus Groups: the importance of interaction between research participants. Sociology of Health \& Illness, 16, 103-121. https://doi.org/10.1111/1467-9566.ep11347023

Knaepen, H., Torres, C., \& Rampa, F. (2015). Making agriculture in Africa climate-smart: From continental policies to local practices. European Centre for Development Policy Management, Briefing Note $\mathrm{N}^{\circ} 80 /$ November 2015.

Koch, I. C., Vogel, C., \& Patel, Z. (2006). Institutional dynamics and climate change adaptation in South Africa. Springer Science, Business Media B.V, Heidelberg, 12, 1323-1339.

Leeuwis, C. (2004). Innovation as a process of network building, social learning and negotiation-implication for transdisciplinary research collaboration, Communication presented at International Transdisciplanary Conference on Development and Conservation of Karst-Region, Hanoi.

Leeuwis, C., \& Hall, A. (2013). Facing the challenges of climate change and food security: the role of research, extension and communication for development. Occasional papers on Innovation in Family Farming, Food and Agriculture Organization of the United Nations.

Lipper, L., Thornton, P., Campbell, B. M., Baedeker, T., Braimoh, A., Torquebiau, E. F. (2014). Climate-Smart Agriculture for Food Security. In: Nature Climate Change, 4(12), 1068-1072.

Macauley, H., \& Ramadjita, T. (2015). Cereal Crops: Rice, Maize, Millet, Sorghum, Wheat. Feeding Africa, an action plan for African agricultural transformation.

Matsaert, H., Ahmed, Z., Islam, N., \& Hussain, F. (2005). Using actor-oriented tools to analyse innovation systems in Bangladesh. Participatory learning and action, 51 April 2005.

Ministère de l'Agriculture. (2016). Annuaire Statistique 2015 du Secteur Développement Rural. Cellule de planification et de statistique/ secteur développement rural, Ministère de l'Agriculture (MA), République du Mali.

Mundy, P., \& Sultan, J. (2001). Information revolutions: how information and communication management is changing the lives of rural people. Wageningen, The Netherlands: Technical Centre for Agricultural and Rural Cooperation (CTA).

Natcher, D., Bachmann, E., Pittman, J., Kulshreshtha, S., Baco, M. N., Akponikpe, P. B. I., \& Peak., D. (2016). Knowledge Diffusion and the Adoption of Fertilizer Microdosing in Northwest Benin. Sustainable Agriculture Research, 5(3), 2016. https://doi.org/10.5539/sar.v5n3p1

Nkwake, A., Magistro, J., \& Horjus, P. (2014) Adapting to the Sahel's changing climate: local approaches an economic and technical feasibility analysis of adaptation techniques in Niger, Burkina Faso and Mali. Catholic Relief Services report.

Pedercini, M., Kanamaru, H., \& Derwisch, S. (2012). Potential impacts of climate change on food security in Mali. Natural Resources Management and Environment Department, FAO, Rome.

Speranza, C. I. (2010). Resilient Adaptation to Climate Change in African Agriculture, German Development Institute Study in Bonn, Germany.

Stabinsky, D. (2014). Climate Smart Agriculture: myths and problems. Heinrich-Böll-Stiffung, The Green Political Foundation. 
Trenberth, K. E. (2007). Observations, surface and atmospheric change, in: S. Solomon et al. (eds.), Climate change 2007. The physical science basis, Working group I contribution to the fourth assessment report of the Intergovernmental Panel on Climate Change, Cambridge: Cambridge University Press;

UNDP. (2012). Food Production and Consumption Trends in Sub-Saharan Africa: Prospects for the Transformation of the Agricultural Sector. UNDP, working paper, Regional Bureau for Africa.

Van Mele, P. (2006). Zooming-in, zooming-out: a novel method to scale up local innovations and sustainable technologies. International Journal of Agricultural Sustainability, 4(2), 131-142.

Van Mele, P., Bentley, J.W. \& Guéi, R. 2011 African Seed Enterprises: Sowing the Seeds of Food Security. Wallingford, UK: CABI. $236 \mathrm{pp}$.

Van Mele, P., Bentley, J., Harun-ar-Rashid, Md. Okry, F., \& van Mourik, T. (2016). Letting Information Flow: Distributing Farmer Training Videos through Existing Networks. Indian Journal of Ecology, 43(1), 545-551.

World Bank, \& CIAT. (2015). Climate-Smart Agriculture in Kenya. CSA Country Profiles for Africa, Asia, and Latin America and the Caribbean Series. Washington D.C.: The World Bank Group.

World Bank. (2007). Population Issues in the $21^{\text {st }}$ Century: The Role of the World Bank. Health, Nutrition and Population (HNP) Discussion Paper. The World Bank, Washington D.C.,

Zoundji, C. G., Okry, F, Vodouhê, D. S., \& Bentley, J. (2016). The distribution of farmer learning videos: Lessons from non-conventional dissemination networks in Benin. Cogent Food \& Agriculture, 2, 1277838. https://doi.org/10.1080/23311932.2016.1277838

Zoundji, C. G., Witteveen, L., S. D. Vodouhê, \& Lie, R. (2017). When baobab flowers and rainmakers define the season: farmers' perceptions and adaptation strategies to climate change in West Africa. International Journal of Plant, Animal and Environmental Sciences, 7(2), https://doi.org/10.21276/Ijpaes

\section{Copyrights}

Copyright for this article is retained by the author(s), with first publication rights granted to the journal.

This is an open-access article distributed under the terms and conditions of the Creative Commons Attribution license (http://creativecommons.org/licenses/by/3.0/). 